Natural Hazards and Earth System Sciences (2003) 3: 593-604

(C) European Geosciences Union 2003

Natural Hazards and Earth System Sciences

\title{
Flood history in the karst environment of Castellana-Grotte (Apulia, southern Italy)
}

\author{
Mario Parise \\ National Research Council - IRPI, Bari, Italy \\ Received: 6 November 2002 - Revised: 27 March 2003 - Accepted: 6 May 2003
}

\begin{abstract}
Karst environments are characterized by peculiar hydrologic features, and in particular by a very limited, if not absent, surface hydrography. Water tends to infiltrate rapidly underground through the complex network of fractures and karstic conduits in the rock mass. However, on the occasion of concentrated rainfall, as well as in case of prolonged precipitation, such network might not be able to allow flowing of large amounts of water, which causes the occurrence of floods. This contribution illustrates the flood history in a classical karst area of Southern Italy, the town of Castellana-Grotte, in Apulia. The oldest part of the town lies at the bottom of a karst valley, which was hit by many flood events in the last centuries. More than twenty of these are here documented, starting from critical analysis of existing publications and documents, integrated with additional historical researches. Aimed at reconstructing the flood history at Castellana-Grotte, the best-documented events are described, together with the main factors, which played a role in distribution and gravity of the related damage. Eventually, some engineering works realized during the first decades of the last century, in order to avoid further damage on the occasion of catastrophic floods, are also described.
\end{abstract}

\section{Introduction}

Floods are the major cause of harmful effects induced by water on society (Yevjevich, 1992). They may occur in many different geological environments, with diverse hydrogeological and morphological characteristics; the resulting damage is often very high, in terms of both casualties and socioeconomic losses. As for the effects of other natural disasters (Bolt et al., 1975; Schuster, 1996), the negative effects on society and the territory extend well beyond the boundaries of the area directly affected by the flood, and there is a great difficulty in determining the overall losses resulting from a single event (Griggs, 1988).

Correspondence to: Mario Parise (cerimp06@area.ba.cnr.it)
For all the types of natural hazards, availability of information on past events has a crucial importance in understanding the phenomenon under study, with particular reference to its spatial and temporal distribution. As regards to floods, studies and analysis dealing with aspects of the history of hydrology and hydraulic engineering are of great interest: they can nowadays rely on paleoflood data, which can result from classical fluvial paleohydrology research (Condie and Lee, 1982; Costa, 1983; Baker, 1987; Williams and Costa, 1988; Nunes Correia, 1991; Martini et al., 2001), and from critical review and analysis of historical chronicles and documents (Stedinger and Cohn, 1986; Jin and Stedinger, 1989; Rossi, 1992; Llasat and Barriendos, 2001; Naulet et al., 2001). The latter, in most of the cases, deals essentially with the impacts that flood events had on man's activities and infrastructure, and/or with the consequent engineering works aimed at mitigating similar effects from future floods.

The present paper belongs to the second category above, and provides a contribution about the use of historical information on floods, aimed at a better comprehension of the flood history of a classical karst area of Southern Italy, the town of Castellana-Grotte, in Apulia. Castellana-Grotte is worldwide famous due to the remarkable, more than $3 \mathrm{~km}$ long and more than $120 \mathrm{~m}$ deep, caves (Fig. 1), which were explored for the first time in 1938, and soon after that became one of the most visited show caves in Europe (Anelli, 1957). Discovery of these caves played an important role in the touristic development of the town that modified its name in 1950, by adding Grotte (which means caves), thus becoming the present Castellana-Grotte.

\section{Floods in karst environments}

Karst areas represent a very distinct type of environment, with marked local and regional differentiation of ecosystems and geotopes that are expressed by their specific morphology, hydrographic and ecological characteristics, and by the complex hydrogeological and engineering-geological conditions 


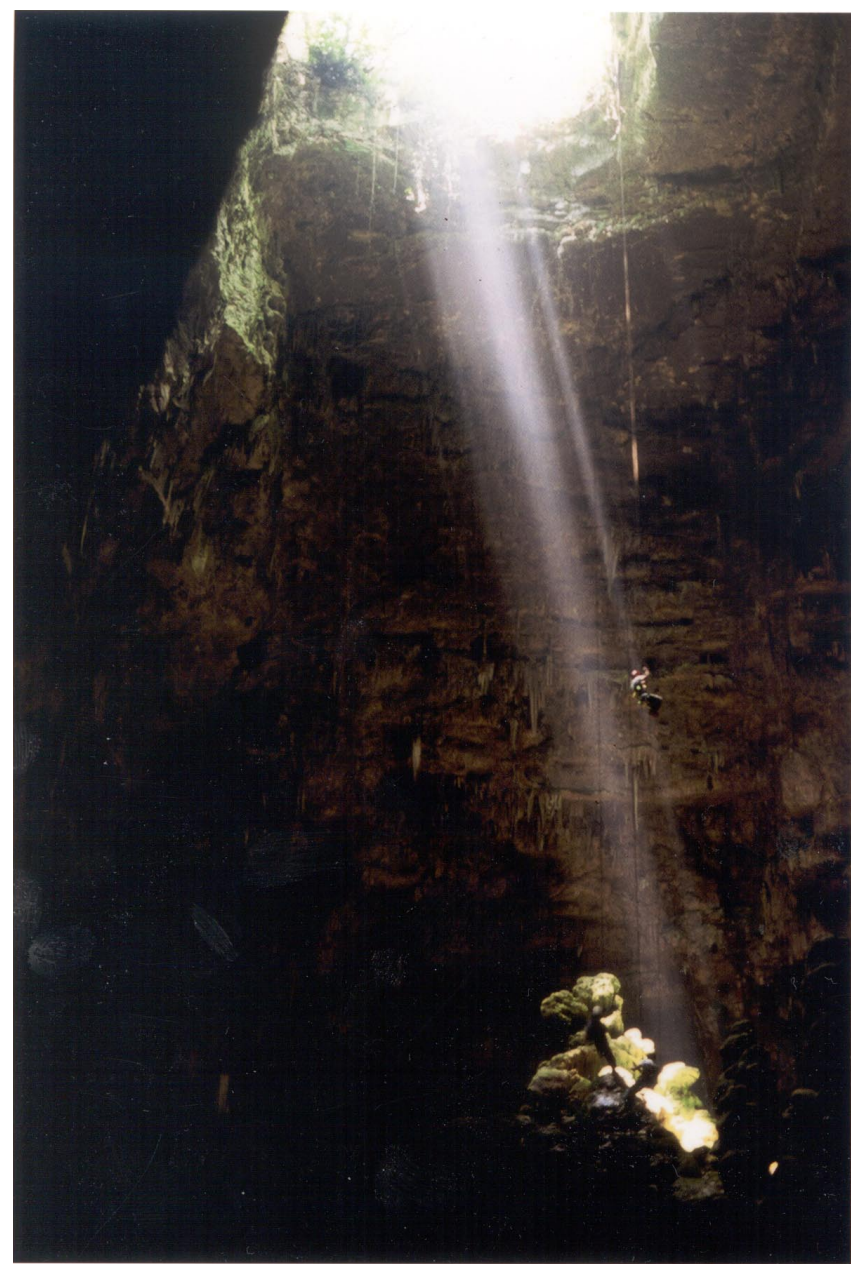

Fig. 1. The $75 \mathrm{~m}$ deep Grave, the entrance to the Castellana Caves (photo courtesy of Gianni Campanella).

(Liszkowski, 1975). In particular, karst environments are characterized by peculiar hydrologic features, and by a very limited, if not absent, surface hydrography (Cvijic, 1918; Nicod, 1972). The outcropping of soluble rocks, which permeability is essentially related to fracturing in the rock mass, further enhanced by the development of karst conduits and cavities, favours the rapid infiltration of water in depth, significantly limiting the surface runoff. Nevertheless, on the occasion of concentrated rainfall, or of prolonged precipitation, the network of fracture and conduits in the rock mass may not be able to allow rapid flowing of large amounts of water. At the surface, changes of the normal drainage ways and formation of temporary lakes may be registered, and floods may occur (White and Reich, 1970; White and White, 1984; Mijatovic, 1987; Molina and Mc Donald, 1987; White, 1990). If buildings and man-made structures are present in the affected area, damages are likely to be expected.

Even when rainfall is not particularly strong, flooding may occur when the landscape has been modified by man: actions such as changes in the water drainage ways through agricultural work, road paving, and clogging of existing swallets

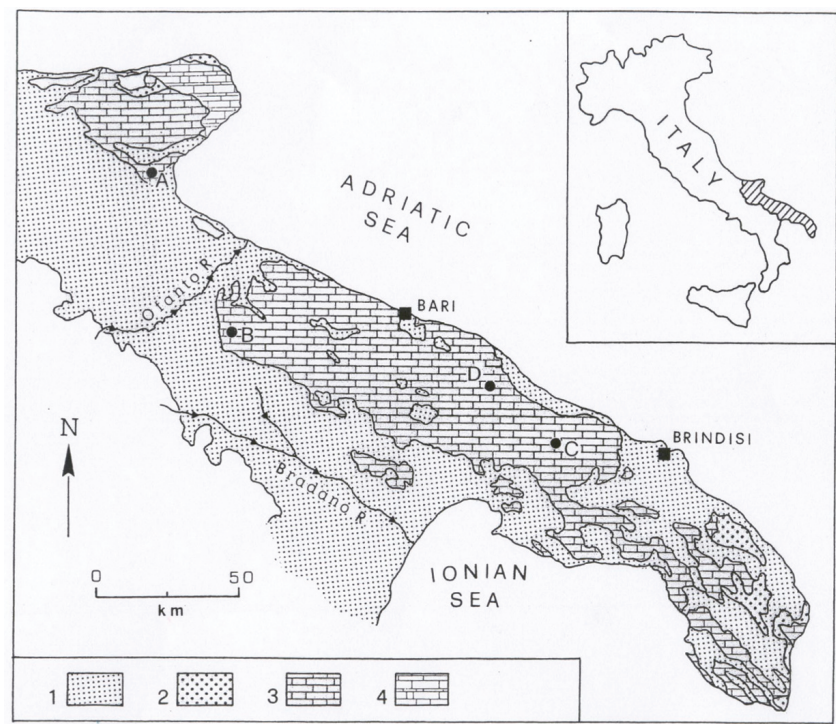

Fig. 2. Location of the study area, and geological sketch of Apulia. 1) alluvial deposits (Pliocene-Pleistocene); 2) bioclastic carbonate rocks (Paleogene) and calcarenites (Miocene); 3) carbonate platform rocks (Upper Jurassic - Cretaceous); 4) scarp and basin chertcarbonate rocks (Upper Jurassic - Cretaceous). Castellana-Grotte is indicated by the black circle and the letter D.

favour the surface runoff and hinders infiltration of water in the underground network.

In karst environment, therefore, it is important to perform a distinction between a core catchment area and a peripheral (or buffer) catchment area, the latter being reactivated only periodically on the occasion of extreme meteorological events (Gillieson, 1996). The situation can be furtherly complicated by spottiness of the rainstorm, that is irregular spatial distribution of the rainfall during the same meteoric event: if the catchment area is wide enough, also rainfall occurring at different sites with varying intensity might be able to produce floods, often with an abruptness and sheer force that are generally typical of events in semi-arid or extreme arid areas (Schick, 1988).

The Apulia region (Fig. 2) is one of the classical karst areas of Italy, being overlaid for most of its extent by carbonate rocks. Many floods have been registered at several locations in the region: to provide a few examples, it is worth to recall here the 1896 flood in Monopoli (Corriere delle Puglie, 1896-97), and that of 1926 in Bari (Baldassarre and Francescangeli, 1987). The latter town was involved in several other floods during the 19th and 20th centuries: the most important were those of 1810, 1827, 1905, and 1916 (Valente, 1905; Melchiorre, 1982).

During the event of November 1926, in particular, $161 \mathrm{~mm}$ of rainfall were registered in three days (4-6 November); the maximum value of $103 \mathrm{~mm}$ occurred between 19:00 and 23:45 LT of 5 November, and was more than a quarter of the mean annual precipitation at the site (that is $600 \mathrm{~mm}$; Baldassarre and Francescangeli, 1987). 


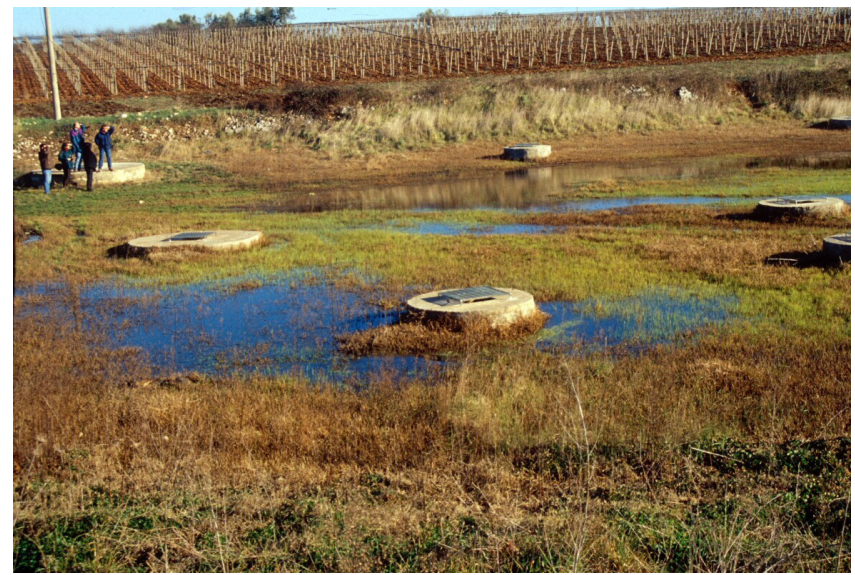

Fig. 3. Karst lake of Chienna, in the southeastern Murge, showing the several wells, built in local limestone rocks, inside the flooded area. In the proximity of this lake, some of the first human settlements of this area, dating back to Neolithic time, have been found (Coppola, 1981).

In most of these occasions, the causes of the severe damage accompanying the flood events had to be looked for, beyond the unusual rainfall values, also in the expansion of the urban area inland, with the consequent coverage of large sectors of land with asphalt and buildings, and the occupation by man of areas that were before naturally dedicated to flow of water lines during intense rainstorms.

\section{Castellana-Grotte}

Apulia geologically represented the foreland during the phases of building up of the Southern Apennines of Italy. Most of the region is made up of thick sequences of limestones and dolomites formed in carbonate platforms during Cretaceous time (Fig. 2); in particular, at Castellana-Grotte outcropping rocks are pelitic mudstones and wackestones of the Lower Coniacian (Upper Cretaceous; Parise and Reina, 2002). Later on, these materials, faulted, deformed, and that were repeatedly affected by karst process, have been partly covered by recent deposits, mostly represented by calcarenites.

The landscape is low lands, and presents landforms of clear karst origin. Many phases of karst have in fact been active, producing an extensive underground network of cavities, caves and conduits, only a limited part of which is explorable by man. As other landscapes where karstification is the main modelling agent, some features can be identified: first of all, the absence, or very limited presence, of surface runoff, the outcropping of residual deposits from karst processes (the so-called terre rosse), the connectivity between the surface and the underground systems, and the need in defining dynamic boundaries for karst catchments. The role of man has also to be stressed, since the landscape has everywhere been strongly modified by anthropogenic interven-

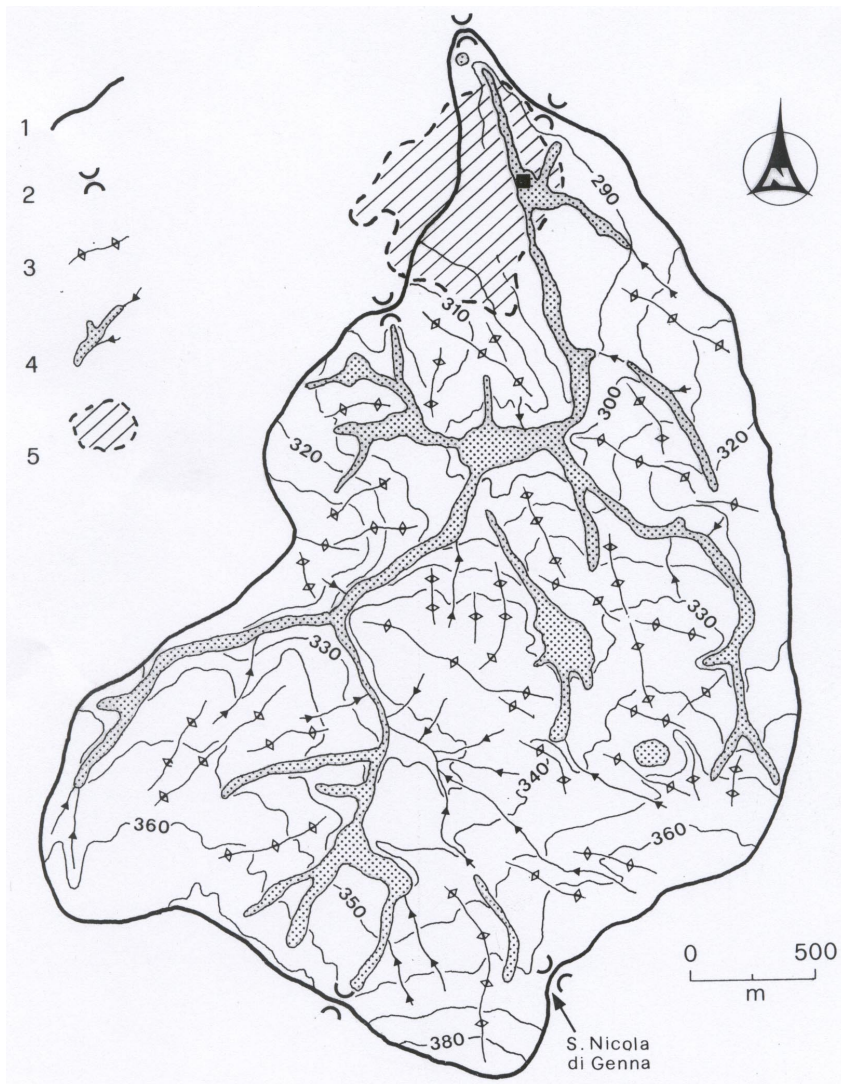

Fig. 4. Karst valley of Castellana-Grotte. 1) boundary of the valley; 2) morphological saddle; 3) main divides; 4) depressions and dolines, and remnants of ancient hydrography; 5) town. The square marks the location of Largo Porta Grande. Contour interval $10 \mathrm{~m}$.

tions, also thanks to the smoothed morphologies that facilitated land use changes. Unfortunately, many of these interventions produced, and still cause today, serious problems in terms of pollution and degradation of the karst environment (Parise and Pascali, 2003).

In the typical karst setting of Castellana and nearby areas, the paucity of water at the ground surface strongly controlled the establishment of the first human settlements in the territory. These, in fact, were located close to karst lakes (Fig. 3), where, due to favourable geological conditions, conservation of the precious resource water, and its exploitation, were possible (Parise, 2002).

The oldest part of Castellana-Grotte lies at the bottom of a karst valley (Figs. 4 and 5), which main morphological features are represented by flat bottom valleys filled with alluvial deposits, detritus and terre rosse. Infilling materials have low permeability, so that on the occasion of intense rainfall most of the runoff occurs at the surface.

These valleys and water lines (locally called lame) are the remnants of the original hydrographic network (Parise, 1999); they are directed toward the northern boundary of the valley, where the most low-lying sector and the town of Castellana-Grotte are located (Fig. 4). In ancient maps 


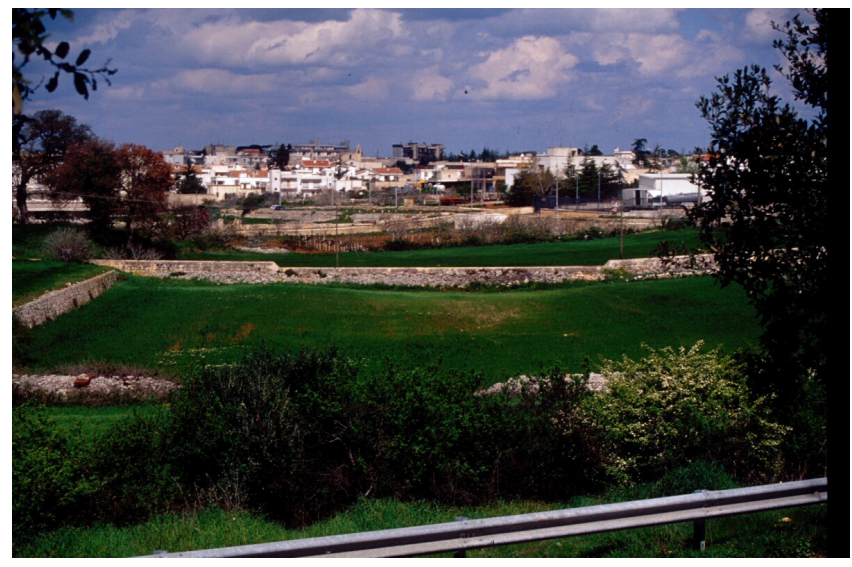

Fig. 5. View from the south of the karst valley of Castellana, showing the town at its lowest sector.

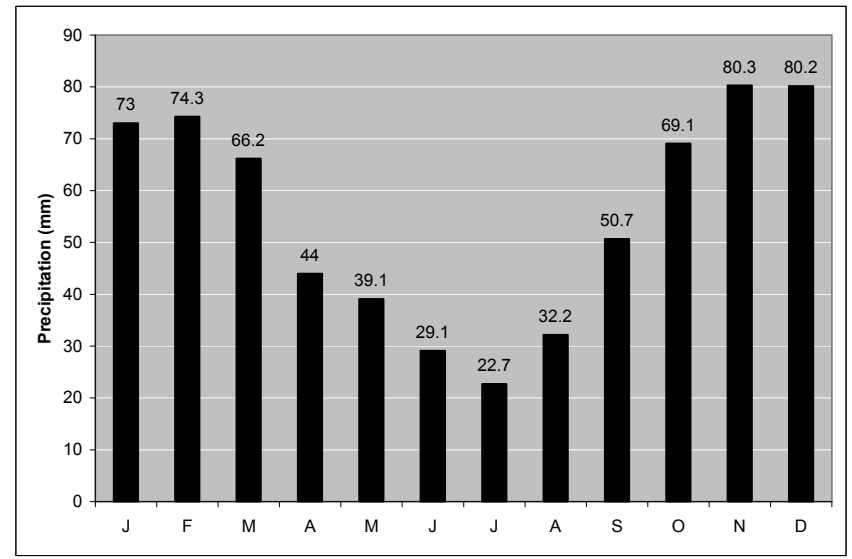

Fig. 6. Average monthly precipitation at Castellana-Grotte rain gauge (period of observation 1951-1996).

the area where Castellana-Grotte lies was indicated as Lago (which means lake; see Colamonico, 1917); this already provides important historical information about the presence of water in the more depressed sector of the valley. Largo Porta Grande is the wide square located at the lowest part of town (see Fig. 4 for location), and has repeatedly been in past times the theatre of flooding events (Orofino, 1990; Pace and Savino, 1995).

Castellana-Grotte is characterized by annual values of rainfall ranging from a minimum of $368.4 \mathrm{~mm}$ (year 1989) to a maximum of $922.8 \mathrm{~mm}$ (year 1957), with mean annual value of $662 \mathrm{~mm}$ (period of observation: 1951-1996). Most of the rainfall occurs during autumn and winter seasons (Fig. 6), and the climate is typically Mediterranean; concentrated rainfall might occur during summer. As for nearby areas, a tendency toward decreasing rainfall is being observed in the last decades (Table 1). Actually, in the last few years a serious hydric crisis in the region, as well as in other sectors of southern Italy, has caused severe problems for supplying

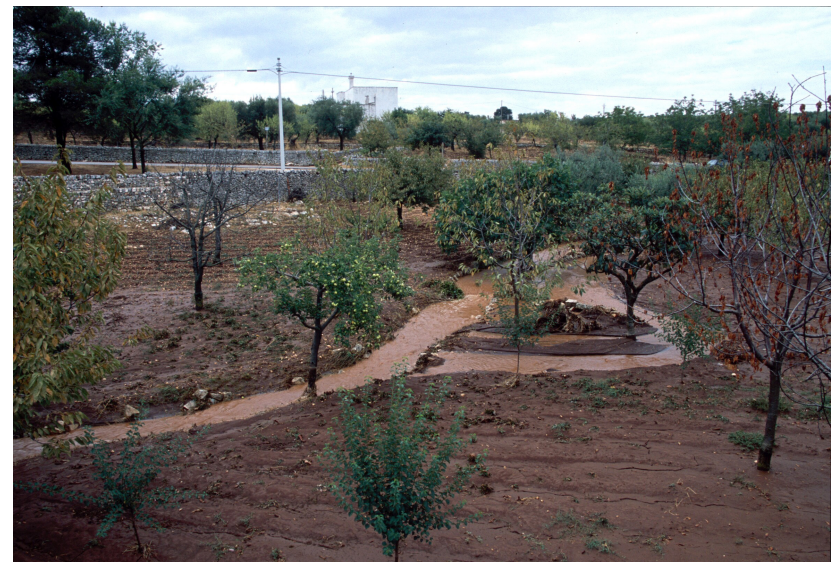

Fig. 7. Flooded area along the Province Road from CastellanaGrotte to Turi, after the intense rainstorms of 26-27 July 2002 (photo courtesy of Giuseppe Savino).

water to the population. On the other hand, flooding events have been recorded recently after prolonged rainfalls in the summer of 2002: the most significant occurred on 26 and 27 July 2002, and caused heavy damage to many towns and rural areas in Apulia (Fig. 7).

\section{The local flood history}

\subsection{Data sources}

In past times Castellana-Grotte has long been affected by floods, which occurrence was related to a combination of some peculiarities of the local karst environment and to land mismanagement by man. Aimed at reconstructing the local flood history, a review of the existing literature about Castellana-Grotte and the surrounding territory, integrated by critical analysis of additional historical documents recently republished (AA.VV., 1996), was performed. A number of sources have been investigated, from national archives and inventories dealing with flooding events, to scientific and historical publications, and to documents and publications of local history. Additional information was also extracted from further sources, which were often helpful in the location of some specific event, and in the description of related damage, but generally did not provide any date of occurrence, or resulted in uncertain dating. Eventually, further useful data were collected through direct inspections and survey of natural and artificial cavities and tunnels in the area.

At a national level, the first archive examined was that of the AVI Project (the acronym AVI stands for Aree Vulnerate in Italia, that is Areas Vulnerable to landslides and floods in Italy); this was commissioned by the Minister of Civil Protection to the National Group for Prevention of Hydrogeological Hazards (GNDCI) of the Italian National Research Council (CNR) to compile an inventory of information on areas historically affected by landslides and floods in Italy 
Table 1. Rainfall values at Castellana-Grotte and nearby rain gauges for the years 1950-1999. Rainfall expressed in millimetres

\begin{tabular}{ccccccccc}
\hline rain gauge & & Castellana & Turi & Conversano & Polignano & Fasano & Locorotondo & Noci \\
\hline elevation (m a.s.1.) & & 290 & 250 & 219 & 24 & 111 & 420 & 420 \\
\hline & years & & & & & & & \\
\hline & $1950-59$ & 716.5 & 814.8 & 772.8 & 663.7 & 725.6 & 700.7 & 892.2 \\
& $1960-69$ & 735.3 & 811.6 & 652.0 & 794.0 & 532.0 & 703.8 & 658.3 \\
$1970-79$ & 696.0 & 553.4 & 640.7 & 643.3 & 636.5 & 628.8 & 643.5 \\
$1980-89$ & 577.3 & 409.2 & 515.5 & 498.5 & 605.8 & - & 595.7 \\
& $1990-99$ & 587.8 & - & 550.1 & 554.8 & 598.9 & 501.6 & 579.9 \\
\hline
\end{tabular}

Table 2. List of hydrological and geological disasters (floods and karst subsidence) at Castellana-Grotte, as extracted from review of existing literature and analysis of historical documents. Events of subsidence are shown in italics. Where available, information on rainfall has been included (number in bold indicates that the rainfall is the maximum value of the month)

\begin{tabular}{|c|c|c|c|c|}
\hline no. & date & source & rainfall & notes and damage \\
\hline 1 & 28 August 1741 & $\begin{array}{r}\text { Sgobba (1896); } \\
\text { Viterbo (1913) }\end{array}$ & & maximum water level $6 \mathrm{~m}$ \\
\hline 2 & 1 November 1784 & Lanera (1972) & & 9 casualties; maximum water level about $5 \mathrm{~m}$ \\
\hline 3 & 19 September 1853 & AA.VV. (1996) & & \\
\hline 6 & 24 September 1888 & AA.VV. (1996) & & \\
\hline 7 & 25 November 1894 & AA.VV. (1996) & & \\
\hline 8 & 9 November 1896 & $\begin{array}{r}\text { Sgobba }(1896) \\
\text { Viterbo }(1913,1972)\end{array}$ & & $\begin{array}{l}4 \text { casualties; maximum water level } 5,40 \text { m; } \\
600 \text { houses uninhabitable; loss of livestock; } \\
\text { severe damage for at least } 2000 \text { people }\end{array}$ \\
\hline 12 & October 1902 & AA.VV. (1996) & & \\
\hline 13 & July 1905 & AA.VV. (1996) & & \\
\hline 14 & 16 November 1954 & AVI Project archive & & \\
\hline 15 & 21 April 1959 & AVI Project archive & $23 \mathrm{~mm}$ & \\
\hline 16 & 8 October 1966 & AVI Project archive & $84.4 \mathrm{~mm}$ & \\
\hline 17 & September 1968 & Zezza (1976) & $\begin{array}{l}31 \mathrm{~mm} \text { in September; note that in } \\
\text { August a total rainfall of } 198.4 \mathrm{~mm} \\
\text { was registered (maximum monthly } \\
\text { value of the year) }\end{array}$ & buildings damaged; evacuation of people \\
\hline
\end{tabular}



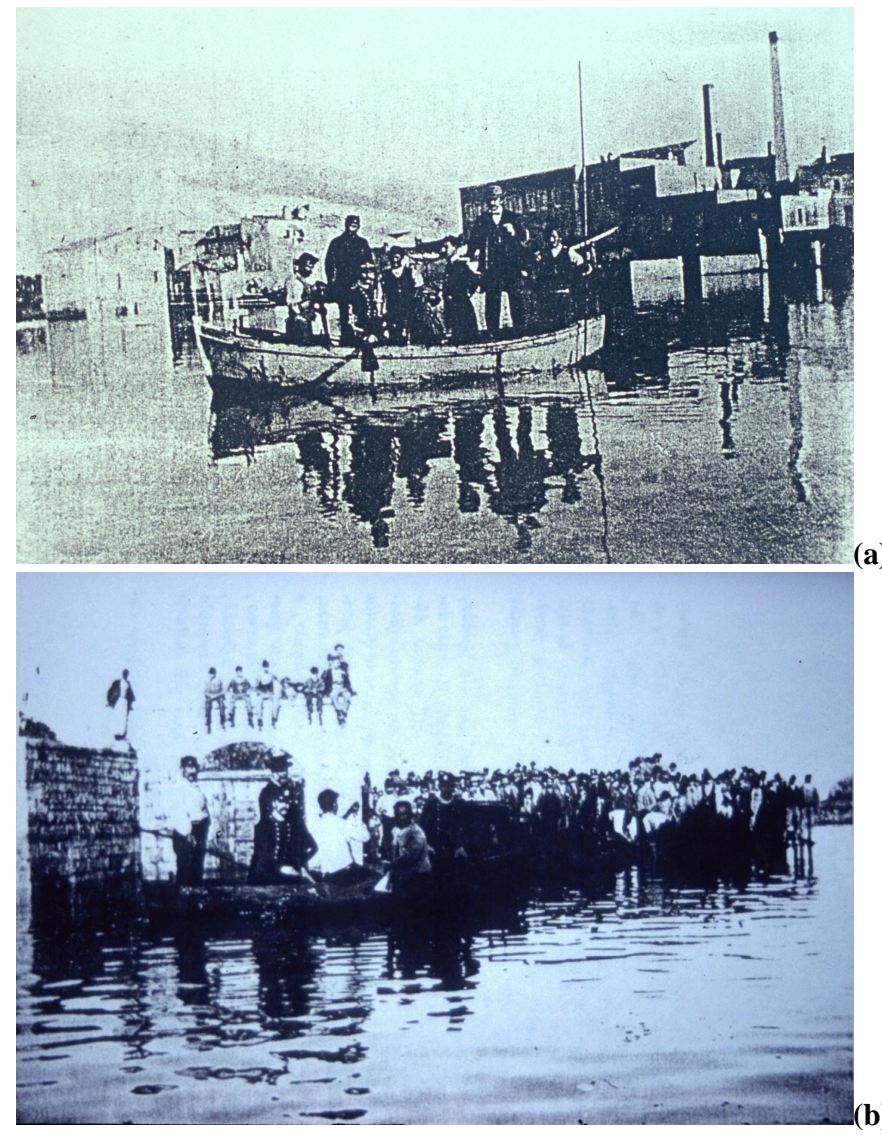

Fig. 8. Historical photos of the 1896 flood at Castellana (after AA.VV., 1996): (a) one of the boats used during rescue operation; (b) after the flood.

(Guzzetti et al., 1994). The information extracted from this archive for Castellana-Grotte regard the most recent events, and also include cases of subsidence caused by karstic cavities in the urban area, as will be described later.

The most interesting and numerous data about the flood history at Castellana-Grotte derived, on the other hand, from publications and documents at a more local level. This was a quite expected result that confirmed what was observed from previous historical researches about natural hazards in southern Italy (Calcaterra and Parise, 2001; Parise et al., 2002).

\subsection{Chronology of flood events}

At Castellana-Grotte, a total of 23 events of hydrological and geological disasters, starting since the 18th century, were obtained through historical analysis and scrutiny of available documents. All the events for which some historical documentation was found are listed in Table 2. No information has been so far found about flooding events prior to the 18th century. However, this aspect is worth to be better examined in the future, through examination and scrutiny of the historical documentation, which is collected at the public library of Castellana-Grotte (where, unfortunately, access

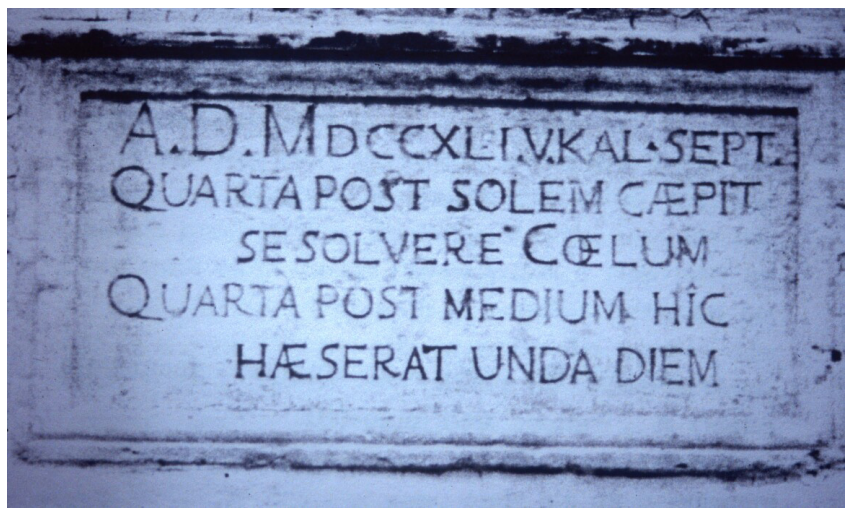

Fig. 9. Historical inscription recalling the 1741 flood (after AA.VV., 1996): on that occasion, the water reached a height of $6 \mathrm{~m}$ at Largo Porta Grande.

for this specific study was not permitted due to works of reorganization of the library), and at several religious archives of the churches in the area.

Looking at the so far identified disasters listed in Table 2, it has to be noted that in a 30-years interval (from 1874 to 1905 ) at the turn of the 20th century, nine events were registered (Table 2); all of them were accompanied by serious damage and, at least in one case, by casualties. The historical documentation was found in local archives and libraries, and consisted of a few works specifically dealing with some of the flood events and of old photographs testifying to their immediate consequences.

The 9 November 1896 flood is the best-documented event, being described in the work by the attorney Antonio Sgobba, which was published few weeks after the disaster. According to this testimony, the rainfall started in the morning, after a few days of intense antecedent rainfall. From 19:00 LT the main event began: there was a strong increase in the intensity of the rain and, after four hours of continuous rainfall, the lowest part of town was completely inundated by a huge lake that reached about one third of the entire town, with height of some $5.4 \mathrm{~m}$ at Largo Porta Grande. Boats had to be carried from Monopoli, the closest town at the seaside, to help people getting out of their houses (Fig. 8). Still today, many historical inscriptions on buildings in the historical centre of Castellana-Grotte recall the sad hours of that day (Fig. 9).

Occurrence of several other flood events, up to the most recent of 26-27 July 2002, still testify the overall fragility of the karst environment at Castellana-Grotte, and the negative impact that the man has often had on the territory: construction of new buildings and roads, which caused diversion of the original water lines, and destruction of the old works (i.e. stone dry walls) aimed at controlling the runoff water, still today contribute to increase the damage to the anthropogenic environment on the occasion of the most intense rainfall. 


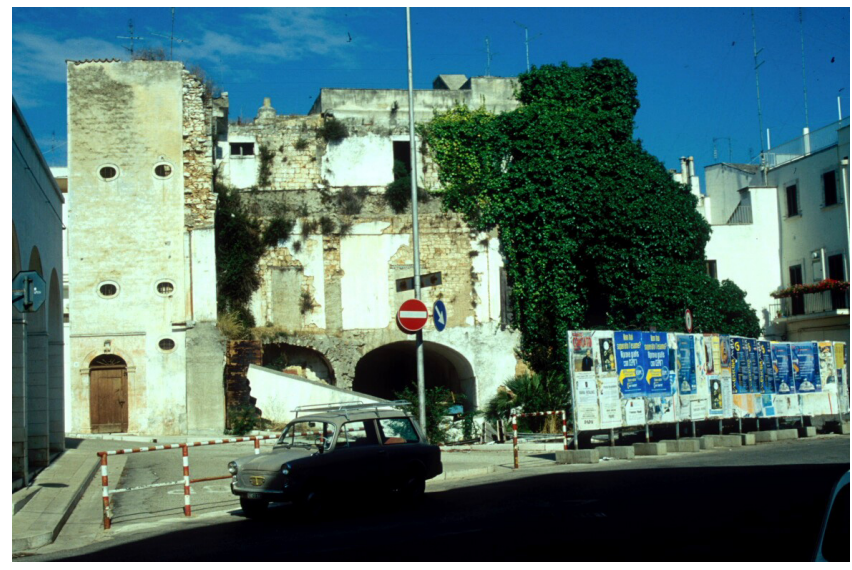

Fig. 10. Buildings involved in cases of subsidence at Largo Porta Grande (photo taken in 1999).

\subsection{Human interactions and impact}

The disastrous effects of the 1896 flood, as well as of those that preceeded it, were favoured by actions of mismanagement of the territory, starting from deforestation of the hills around Castellana, severely carried out since 1700 . Deforestation was mostly performed to provide wood for heating during the winter season or for industrial activities, and to conquer new pieces of land to agriculture. This phenomenon was very typical of large areas of the Mediterranean Basin, where it was favoured by expansion of settlements and agricultural practices, which eventually resulted in promoting soil degradation (Gams, 1991; Gams et al., 1993; Frumkin, 1999; Gams and Gabrovec, 1999). In southern Italy, where extensive deforestation occurred in the 18th and 19th centuries, many hydro-geomorphological problems (mostly shallow landslides and erosion) have still to be related to destruction of the vegetational cover that was originally present on slopes (Sorriso Valvo, 1993; Parise and Wasowski, 2000).

The Murge, that is the part of Apulia where CastellanaGrotte is located, were severely involved in deforestation practices, and today only a very few remnants of the ancient wood cover still exist in the area (Vita, 1972). As remarked in several testimonies (Viterbo, 1913; AA.VV., 1996), the great part of the oak trees that characterized the slopes surrounding the karst valley of Castellana-Grotte were cut in the last two centuries, and replaced with olive trees and vines.

In addition, as a further change of the original setting at Castellana-Grotte, since the second half of the 19th century the natural system of caves and channels there existing was strongly changed by man. It is worth reporting here an example: in the 1880-90's the monks at the church of S. Francesco di Paola (today devoted to S. Giuseppe, located at the east side of Largo Porta Grande), after many requests, were eventually authorized to infill the several swallets and caves in the area, and to build large reservoirs in order to better cultivate their properties (AA.VV., 1996). Infiltration of water in the underground system of cavities was thus obstructed. Many of such activities are again registered in historical documents from various sources, found in private and public archives at Castellana-Grotte and nearby towns. All of these actions of mismanagement played a very important role in producing greater negative effects on the occasion of the floods.

The presence of a thick network of subterraneans in the area, both natural and man-made, recently received further evidences by finding of old structures in 2000 and 2002: in particular, the ancient channel which was identified during some construction works in December 2000 (Manghisi and Pace, 2001) was probably part of the complex drainage system there existing, or, alternatively, a tunnel connecting reservoirs located at different sites of the square.

These subterraneans made still more complex the karst environment at Castellana-Grotte, and increased its high fragility, as was repeatedly demonstrated by other geological disasters that occurred at the very same site that was the theatre of the main floods (Largo Porta Grande; Fig. 10). Several cases of subsidence due to presence of underground cavities partly filled with colluvial deposits and terre rosse had to be registered since 1968 (Table 2); in more than one occasion, collapse of the above buildings, that had eventually to be evacuated, resulted.

Subsidence phenomena related to the presence of underground cavities due to karst processes are typical of many karst areas (Nicod, 1972; White, 1988; Palmer, 1990). Subterranean erosion may cause collapse of the cavity's roof and the breakthrough of the cavities to the ground surface, with formation of sinkholes. Either natural or man-made, this phenomenon affects carbonate formations subject to karstification in many areas of the world (Jennings et al., 1965; Calembert, 1975; Stringfield and Rapp, 1976; Cotecchia, 1980; Soriano and Simòn, 2002), and is frequently encountered during road constructions or other engineering works in karstic areas (Péwé, 1990; Cavounidis et al., 1996; Roje-Bonacci, 1997).

\subsection{Engineering works}

After the 1896 event, many works were designed and realized in the lowest part of Castellana to facilitate infiltration of water underground. Actually, even before that, the need to realize hydraulic works was strongly felt in the town: the first project was designed to use some of the karst cavities in the area, where at least 4 deep shafts were known, by connecting them through horizontal tunnels to allow the amount of water to penetrate in depth and not to be collected at the surface on the occasion of intense precipitation. With this aim, in 1865 the shafts called "Gravinelle" were enlarged at the entrance, and a double opening to facilitate inflow of the waters was realized (Viterbo, 1913). Gravinelle is a karst shaft, some $40 \mathrm{~m}$ deep, created by karst processes which have enlarged a fracture in the rock mass (Figs. 11 and 12).

Nevertheless, it was clear already at that time that this first work could not be considered as resolutive for the flooding problems at Castellana on the occasion of major 

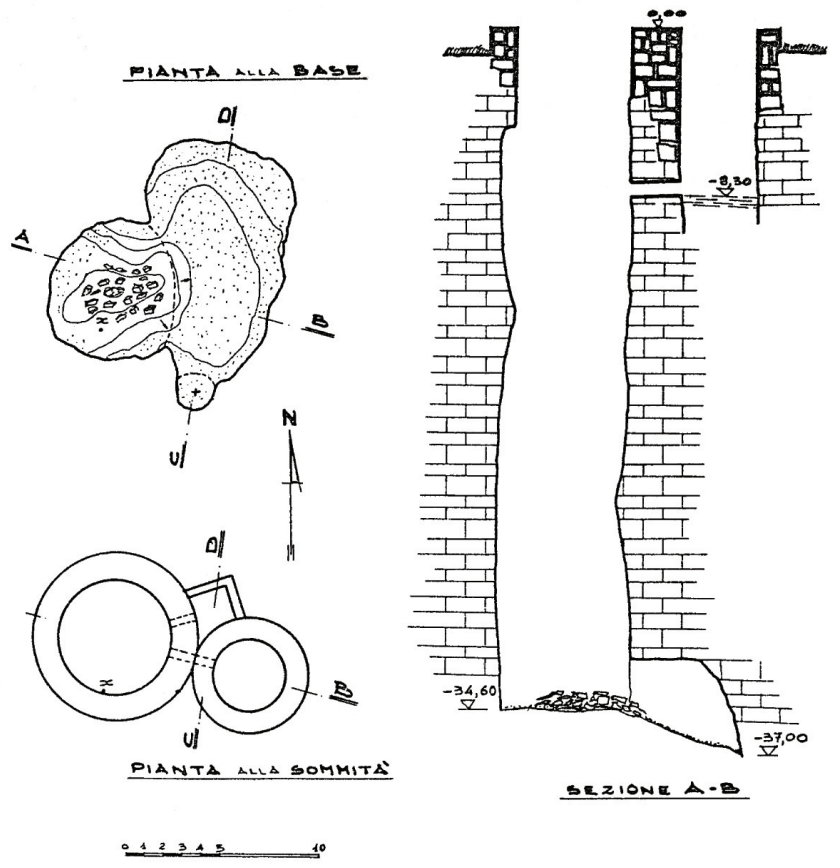

Fig. 11. Plan and section of the Gravinelle, the deep shafts present at the southern end of Largo Porta Grande (survey and drawing by Franco Orofino). The figure shows the plan at the bottom of the shafts (pianta alla base) and at their entrance (pianta alla sommità), and the vertical section (sezione). Units in meters.

rainstorms. Thus, another design, whose expense was estimated in 100000 Italian lire of the time, was realized; this sum had originally to be covered by the Castellana Municipality. Lack of funding from the Municipality, unfortunately, resulted in delay of the works.

After further floods, including that catastrophic of 9 November 1896, a new project was designed, this time at the expense of the Italian State. Again, however, a new delay had to be registered, this time caused by the catastrophic 1909 Messina earthquake: the tragic aftermath of that event, and the very severe damage registered in Messina and Reggio Calabria, moved toward the southernmost tip of Italy most of the funds from the Italian government. Thus, only in 1911 the work eventually began at Castellana, to be completed two years later (Viterbo, 1913). At a depth of about $10 \mathrm{~m}$, the Gravinelle were connected through an artificial tunnel (called Canalone, which means Big Channel; Figs. 13 and 14) to other shafts to the north, located at a distance of, respectively, about $1 \mathrm{~km}$ and $2.5 \mathrm{~km}$ (Manghisi, 1987). In addition, a second tunnel to be used as spillway was also built, for a length of $336 \mathrm{~m}$. Another deep shaft (called "Gravaglione"), the only one left undisturbed after the works realized by the monks of S. Francesco di Paola, is still present along the Canalone; since 1913, it is used to drain the sewerage coming from the town.

This system, designed to mitigate the risk from new floods, actually worked. After these hydraulic engineering works, only minor floods, with very limited damage when compared to those caused by previous events, were registered at Castellana.

All of the works described above belong to the so-called "flood-damage mitigation" (Linsley and Franzini, 1979), "flood hazard reduction" (Rossi, 1992), or "coping with floods measures" (Yevjevich, 1992), that is all those measures, with necessary policies and strategies of implementation, that a society may apply to prevent or mitigate flood damages. Specific flood mitigation measures, including structural and non structural measures, and soil conservation actions, are greatly variable depending on the physical and morphological characteristics of the area, and in particular on the main hydrogeological features of outcropping rocks.

\section{Discussion}

Review of available publications and documents, and historical research performed for this study, resulted in collection of many information about the flood history in the classical karst area of Castellana-Grotte, and the engineering works realized at the site after the catastrophic event of 1896.

Historical research on natural hazards provides useful insights toward a better comprehension of the phenomena under study, and their frequency and effects on the anthropogenic environment. This is in particular true for floods: as stated by Baker et al. (2000), integration provided by availability of historical information is crucial for paleoflood hydrology, that is the science of reconstructing the magnitude and frequency of large floods using geological evidence and a variety of interdisciplinary techniques. This integration is of particular importance as regards the floods of greatest concern to humans that are those associated with climatic conditions most like the present.

At Castellana-Grotte, in all of the documented flood events (listed in Table 2), direct and indirect impacts had to be registered, where direct impacts include the loss of human lives, of livestock and wild animals, of property and current industrial, agricultural and service sector production or delivery; indirect impacts, on the other hand, result from the propagation of direct economic losses through the regional economy (Yevjevich, 1992; Williams, 1993).

The main lesson, which can be drawn from the flood history so reconstructed at Castellana-Grotte, highlights once again the great fragility of karst environments, and, at the same time, the need to adequately manage natural disasters in these settings. As regards this latter point, it has to be noted that the engineering works realized at the turn of the century at Castellana were certainly good interventions in the framework of a policy of management and safeguard of the environment.

The need to keep a historical memory of the hydrological and geological disasters at Castellana-Grotte is today much higher than in the past, since the minor frequency of catastrophic events in the last decades, which is probably also due to changes in climatic conditions, resulted in loss of memory 

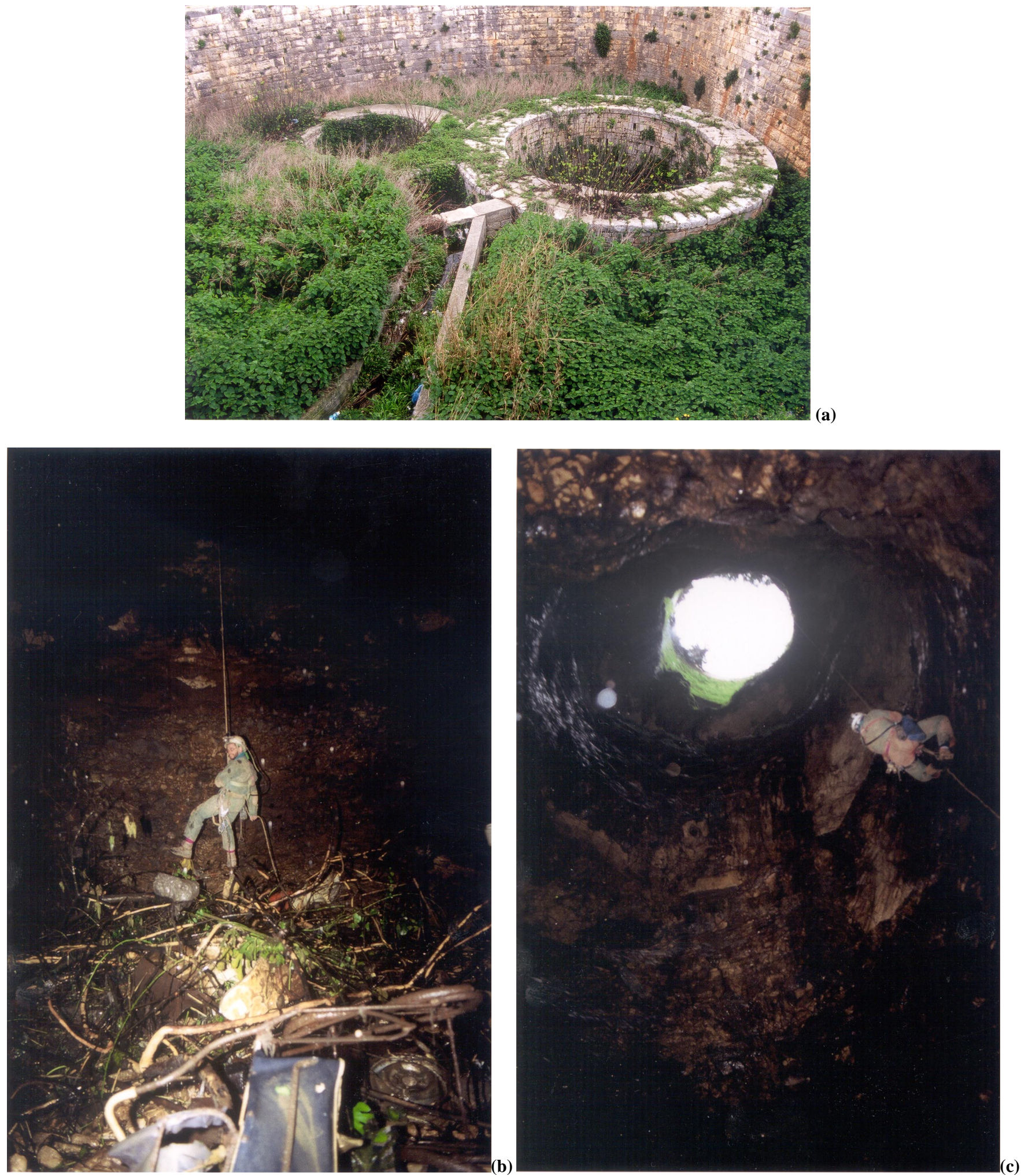

Fig. 12. The Gravinelle: (a) the cave double entrance; (b) the bottom of the cave, showing waste materials of different kind; (c) ascending the 40-m deep shaft (photos $12 \mathrm{~b}$ and $12 \mathrm{c}$ courtesy of Domenico Sgobba). 


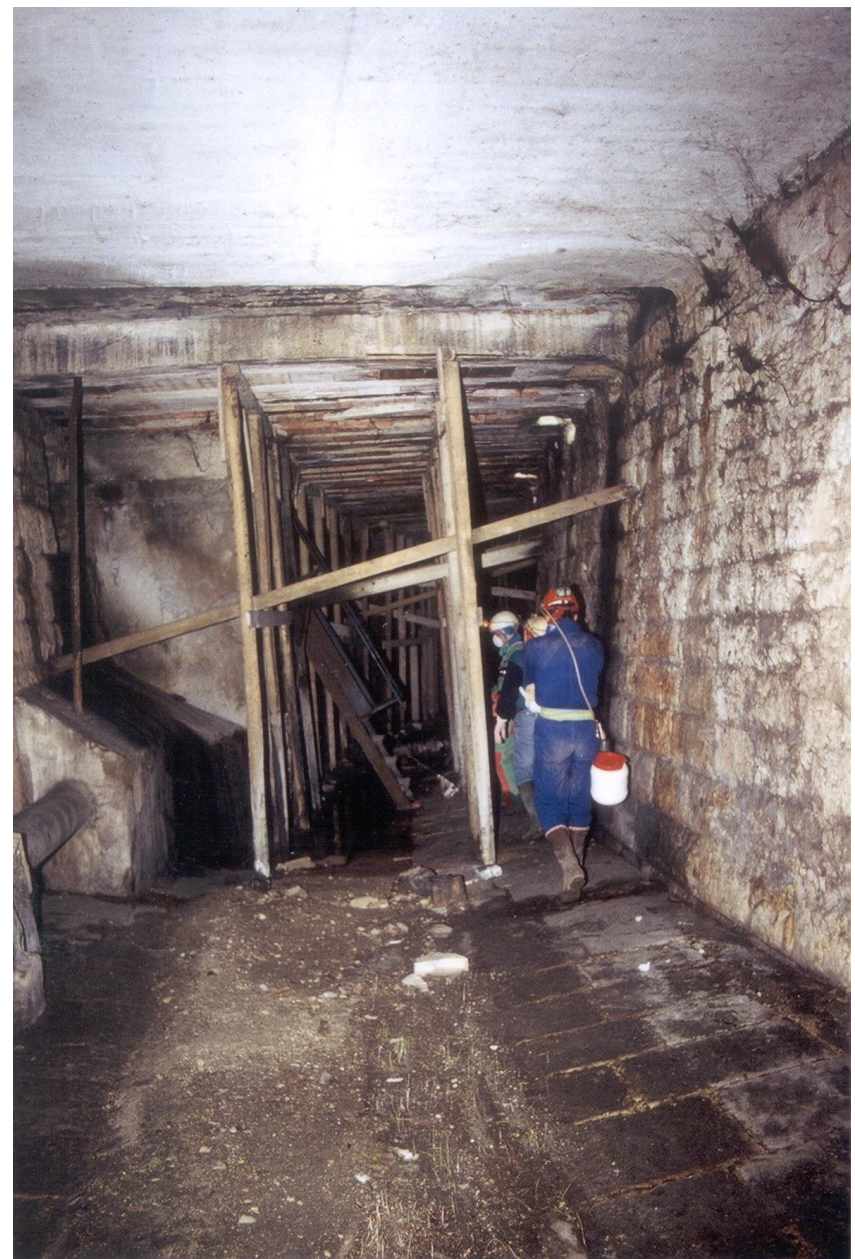

Fig. 13. Inside the Canalone (photo courtesy of Domenico Sgobba).

of the hazard related to the peculiarities of the karst environment. On the other hand, in the process of mitigation of the specific hazard, a great role should be played by keeping maintenance of the engineering works realized at the beginning of last century. Their lack of maintenance, in fact, together with the use of caves to waste solid materials (still a very diffuse habit), and the wide expansion of urbanization, with new buildings and roads covering the original natural landscape, might result in the short- as well as the long-term to likely future problems. In many cases it has recently been shown that the lack of maintenance of structures designed for hazard mitigation actually resulted in increasing the damage deriving from occurrence of the event.

In conclusion, from the documentation that has been found so far, concerning the floods at Castellana-Grotte, the history in this small town of the apulian karst teaches us that the effects produced by man on very fragile environments can be very severe and result in further damages during floods. The most worrying consideration is probably that, with time, the memory of many of these episodes gets lost, and new works, potentially negative in terms of vulnerability (sensu Varnes,

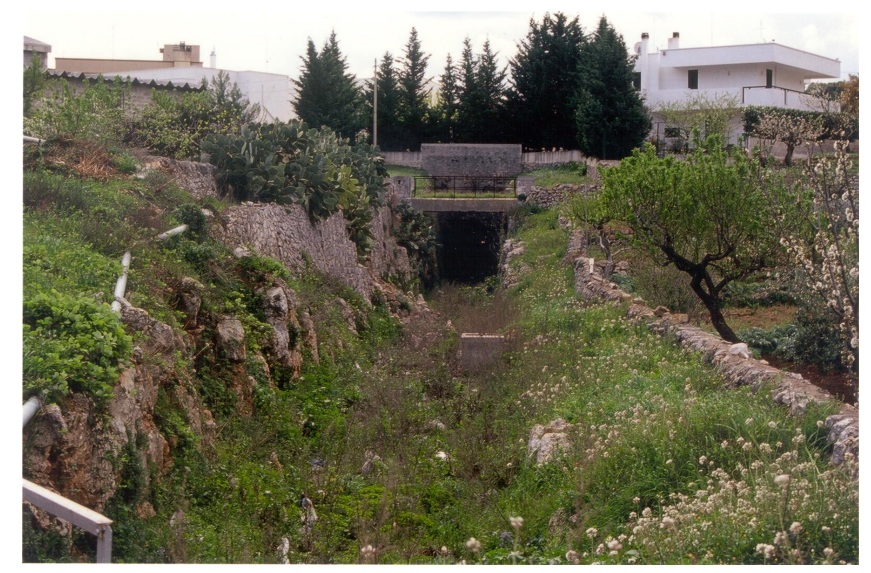

Fig. 14. Northern exit of the Canalone.

1984), are realized. Scientists, as well as technicians and administrators in charge of the land management, should try to keep memory of the past occurrence of these events, since their knowledge and documentation, and the dissemination of these information to the population, are the first steps toward mitigation of the risk related to natural hazards.

Acknowledgements. I express my most sincere thanks to Gianni Campanella, Pino Pace, Giuseppe Savino and Domenico Sgobba (all of them speleologists from Gruppo Puglia Grotte of CastellanaGrotte) for their help and assistance during this study.

\section{References}

Anelli, F.: Guida per la escursione II. Bari - Alberobello - Selva di Fasano - Castellana Grotte - Bari, Proc. XVII Congr. Geogr. It., Bari, 23-29 April 1947, 4, 69-120, 1957.

AA.VV.: Le inondazioni a Castellana, edited by CE.RI.CA., Castellana-Grotte, 79, 1996.

Baker, V. R.: Paleoflood hydrology and extraordinary flood events, J. Hydrol., 96 (1/4), 79-99, 1987.

Baker, V. R., Webb, R. H., and Kyle House, P.: The scientific and societal value of paleoflood hydrology, in: Ancient floods, modern hazards, edited by Kyle House, P., Webb, R. H., Baker, V. R., and Levish, D. R., AGU, Washington, DC, 1-19, 2000.

Baldassarre, G. and Francescangeli, R.: Osservazioni e considerazioni sulla inondazione del 6 novembre 1926 in Bari e su un relativo deposito, Mem. Soc. Geol. It., 37, 7-16, 1987.

Bolt, B. A., Horn, W. L., Macdonald, G. A., and Scott, R. F.: Geological hazards, Springer-Verlag, New York, 328, 1975.

Calcaterra, D. and Parise, M.: The contribution of historical information in the assessment of landslide hazard, in: The use of historical data in natural hazard assessment, edited by Glade, T., Albini, P., and Frances, F., Kluwer Academic Publ., 201-216, 2001.

Calembert, L.: Problemes de geologie de l'ingenieur en regions karstiques, Bull. Int. Ass. Eng. Geology, 12, 93-132, 1975.

Cavounidis, S., Marinos, P., and Papadopulos, T.: Subsidence investigation for reservoir, Proc. 7th Int. Symp. on Landslides, Trondheim (Norway), 2, 675-681, 1996. 
Colamonico, C.: Le conche carsiche di Castellana in Terra di Bari, Boll. R. Soc. Geogr. It., IX-XII, 1-39, 1917.

Condie, R. and Lee, K. A.: Flood frequency analysis with historic information, J. Hydrol., 58, 47-61, 1982.

Coppola, D.: Le più antiche tracce di popolamento umano nel territorio: il Paleolitico, in: Il popolamento antico nel sud-est barese, AA.VV., Museo Civico di Conversano, 21-35, 1981.

Corriere delle Puglie, daily newspaper, Bari, 1896-1897.

Costa, J. E.: Paleohydraulic reconstruction of flash-flood peaks from boulder deposits in the Colorado Front Range, Geol. Soc. Am. Bull., 94, 986-1004, 1983.

Cotecchia, V.: Review of subsidence phenomena in Italy and the world, in: Hommage a Leon Calembert, Liège, Editions Georges Thone, 72, 1980.

Cvijic, J.: Hydrographie souterraine et évolution morphologique du karst, Rev. Trav. Inst. Géogr. Alpine, VI, 375-426, 1918.

Frumkin, A.: Interaction between karst, water and agriculture over the climatic gradient of Israel, Int. J. Speleol., 28 B, 99-110, 1999

Gams, I.: The origin of the term karst in the time of transition of Karst (Kras) from deforestation to forestation, Proc. Int. Conf. on Environ. Changes in Karst Areas, Quad. Dip. Geografia, Univ. Padova, 13, 1-8, 1991.

Gams, I. and Gabrovec, M.: Land use and human impact in the Dinaric karst, Int. J. Speleol., 28 B (1/4), 55-70, 1999.

Gams, I., Nicod, J., Julian, M., Anthony, E., and Sauro, U.: Environmental change and human impacts in the Mediterranean karsts of France, Italy and the Dinaric region, Catena, suppl. 25, 59-98, 1993.

Gillieson, D.: Caves, Blackwell Publishers, Oxford, 324, 1996.

Griggs, G. B.: Impact of the January 1982 flood in Santa Cruz County, in: Landslides, floods, and marine effects of the storm of January 3-5, 1982, in the San Francisco Bay Region, California, edited by Ellen, S. D. and Wieczorek, G. F., , U.S. Geol. Survey Prof. Paper, 1434, 205-227, 1988.

Guzzetti, F., Cardinali, M., and Reichenbach, P.: The AVI Project: a bibliographical and archive inventory of landslides and floods in Italy, Environ. Management, 18 (4), 623-633, 1994.

Jennings, J. E., Brink, A. B., Louw, A., and Gowan, G. D.: Sinkholes and subsidence in the Transvaal dolomites of South Africa, Proc. 6th Int. Conf. Soil Mechanics, 1965.

Jin, J. and Stedinger, J. R.: Flood frequency analysis with regional and historical information, Water Resources Research, 25, 925936, 1989.

Lanera, M.: Fonti per la storia di Castellana, Fogli per Castellana, 2, 1972.

Linsley, R. K. and Franzini, J. B.: Water Resources Engineering, McGraw-Hill, New York, 3rd edition, 1979.

Liszkowski, J.: The influence of karst on geological environment in regional and urban planning, Bull. Int. Ass. Eng. Geology, 12, 49-51, 1975.

Llasat, M. C. and Barriendos, M.: Availability and potential of historical flood series in the Iberian Peninsula (14th-20th centuries), in: The use of historical data in natural hazard assessment, edited by Glade, T., Albini, P., and Frances, F., Kluwer Academic Publ., 131-140, 2001.

Manghisi, V.: Nota introduttiva alla conoscenza del Canalone (Castellana-Grotte, Bari), Proc. 2nd Conv. Naz. Spel. Urbana, Naples, 1-2 March 1985, 97-102, 1987.

Manghisi, V. and Pace, P.: Un'antica galleria sotterranea scoperta a Castellana Grotte, Puglia Grotte, boll. Gruppo Puglia Grotte, Castellana-Grotte, 71-76, 2001.
Martini, I. P., Baker, V. R., and Garzon, G.: Flood and megaflood processes and deposits, Recent and ancient examples, Int. Ass. Sedimentologists, spec. publ. series, 322, 2001.

Melchiorre, V. A.: Bari nel tempo, Adda editore, Bari, 1982.

Mijatovic, B. F.: Catastrophic flood in the polje of Cetinje in February 1986, a typical example of the environmental impact of karst, in: Proc. 2nd Multidisciplinary Conf. on Sinkholes and the Environmental Impacts of Karst, Orlando, 9-11 February 1987, edited by Beck, B. F., and Wilson, W. L., 299-303, 1987.

Molina, M. and Mc Donald, F.: Sinkhole management and flooding in Jamaica, in: Proc. 2nd Multidisciplinary Conf. on Sinkholes and the Environmental Impacts of Karst, Orlando, 9-11 February 1987, edited by Beck, B. F. and Wilson, W. L., 293-298, 1987.

Naulet, R., Lang, M., Coeur, D., and Gigon, C.: Collaboration between historians and hydrologists on the Ardeche River (France), in: The use of historical data in natural hazard assessment, edited by Glade, T., Albini, P., and Frances, F., Kluwer Academic Publ., 113-129, 2001.

Nicod, J.: Pays et paysages du calcaire, Presses Universitaires de France, Paris, 242, 1972.

Nunes Correia, F.: Rainfall and floods. Hydrologic studies, in: Prevention and control of landslides and other mass movements, edited by Almeida-Teixeira, M. E., Fantechi, R., Oliveira, R., and Gomes Coelho, A., Commission of the European Communities, Report EUR 12918 EN, 3-19, 1991.

Orofino, F.: Castellana-Grotte: le vicende storiche di Largo Porta Grande, Itinerari Speleologici, ser. II, 4, 39-46, 1990.

Pace, P. and Savino, G.: Largo Porta Grande e la conca carsica di Castellana-Grotte, Umanesimo della Pietra-Verde, 10, 35-44, 1995.

Palmer, A. N.: Groundwater processes in karst terrains, in: Groundwater geomorphology: the role of subsurface water in earthsurface processes and landforms, edited by Higgins, C. G. and Coates, D. R., Geol. Soc. Am., spec. paper, 252, 177-209, 1990.

Parise, M.: Morfologia carsica epigea nel territorio di CastellanaGrotte, Itinerari Speleologici, ser. II, 8, 53-68, 1999.

Parise, M.: Caratteri geologici e geomorfologici dei laghi carsici di Conversano (Murge di Sud-Est, Puglia), Grotte e Dintorni, 3, 43-88, 2002.

Parise, M. and Pascali, V.: Surface and subsurface environmental degradation in the karst of Apulia (southern Italy), Environmental Geology, 44,247-256, 2003.

Parise, M. and Reina, A.: Geologia delle Grotte di Castellana, Grotte e Dintorni, 4, 221-230, 2002.

Parise, M. and Wasowski, J.: Fenomeni di dissesto nell'Appennino Dauno, ed implicazioni per il patrimonio archeologico e storico-culturale, Proc. Conf. GeoBen 2000, Torino (Italy), 7 9 June 2000, 749-756, 2000.

Parise, M., Calcaterra, D., and Palma, B.: Historical data analysis of landsliding and flood events in Campania (Italy), as a tool for the assessment of the landslide hazard, Proc. 1st European Conf. on Landslides, Prague (Czech Republic), 269-276, 2002.

Péwé, T. L.: Land subsidence and earth-fisure formation caused by groundwater withdrawal in Arizona; a review, in: Groundwater geomorphology: the role of subsurface water in earthsurface processes and landforms, edited by Higgins, C. G. and Coates, D. R., Geol. Soc. Am., spec. paper, 252, 219-233, 1990.

Roje-Bonacci, T.: Influence of the fluctuation of groundwater levels upon the formation of sinkholes, Proc. Int. Conf. "Engineering Geology and the Environment", Athens, 1, 997-1002, 1997.

Rossi, G.: Historical development of flood analysis methods, Proceedings of the NATO-ASI Conference on "Coping with floods", 
Erice, 3-15 November 1992, 19-41, 1992.

Schick, A. P.: Hydrologic aspects of floods in extreme arid environments, chapter 12 in: Flood geomorphology, edited by Baker, V. R., Kochel, K. C., and Patton, P. C., 189-203, 1988.

Schuster, R. L.: Socioeconomic significance of landslides, in: Landslides. Investigation and mitigation, edited by Turner, A. K. and Schuster, R. L., Transp. Res. Board, sp. Report, 247, Nat. Acad. Press, 12-35, 1996.

Sgobba, A.: Della inondazione avvenuta in Castellana il 9 novembre 1896, Stabilimento Tipografico N. Ghezzi, Monopoli, 15, 1896.

Soriano, M. A. and Simòn, J. L.: Subsidence rates and urban damages in alluvial dolines of the Central Ebro basin (NE Spain), Environmental Geology, 42 (5), 476-484, 2002.

Sorriso Valvo, M.: The geomorphology of Calabria: a sketch, Geogr. Fis. Dinam. Quat., 16, 75-80, 1993.

Stedinger, J. R. and Cohn, T. A.: Flood frequency analysis with historical and paleoflood information, Water Resources Research, 22, 785-793, 1986.

Stringfield, V. T. and Rapp, J. R.: Land subsidence resulting from withdrawal of groundwater in carbonate rocks, Proc. 2nd Int. Symp. on Land Subsidence, Anaheim (USA), 1976.

Valente, G.: Il torrente Picone ed il piano regolatore della Città di Bari, Rassegna Tecnica Pugliese, 4 (4), 1905.

Varnes, D. J.: Landslide hazard zonation: a review of principles and practice, Unesco, Paris, Natural Hazards, 3, 63, 1984.

Vita, F.: Ultimi lembi di bosco a Castellana Grotte, Umanesimo della Pietra-Verde, 2, 27-33, 1972.
Viterbo, M.: Castellana e le alluvioni attraverso i secoli, Rassegna Pugliese, 28, 1-23, 1913.

Viterbo, M.: Castellana nella preistoria, Fogli per Castellana, October 1972, 8-45, 1972.

White, E. L. and Reich, B. M.: Behaviour of annual floods in limestone basins in Pennsylvania, J. Hydrol., 10, 193-198, 1970.

White, E. L. and White, W. B.: Flood hazards in karst terrains: lessons from the Hurricane Agnes storm, in: Hydrogeology of karst terrains, edited by Burger, A. and Dubertret, L., 1, 261264, 1984.

White, W. B.: Geomorphology and hydrology of karst terrains, Oxford University Press, 464, 1988.

White, W. B.: Surface and near-surface karst landforms, in: Groundwater geomorphology: the role of subsurface water in earth-surface processes and landforms, edited by Higgins, C. G. and Coates, D. R., Geol. Soc. Am., spec. paper, 252, 157-175, 1990.

Williams, G. P. and Costa, J. E.: Geomorphic measurements after a flood, chapter 4 in: Flood geomorphology, edited by Baker, V. R., Kochel, K. C., and Patton, P. C., 65-77, 1988.

Williams, P. W.: Environmental change and human impact on karst terrains: an introduction, Catena, suppl. 25, 1-19, 1993.

Yevjevich, V.: Floods and society, Proceedings of the NATOASI Conference on "Coping with floods", Erice, 3-15 November 1992, 11-17, 1992.

Zezza, F.: Significance of the subsidence collapse phenomena in the carbonatic areas of southern Italy, Geol. Appl. e Idrogeol., 11, 123-132, 1976. 